\title{
Capsular Contracture
}

National Cancer Institute

\section{Source}

National Cancer Institute. Capsular Contracture. NCI Thesaurus. Code C50478.

The tightening of scar tissue that forms around the implant. 